\title{
EFEK HETEROSIS DARI HIBRIDA IKAN LELE UNGGUL DI NUSA TENGGARA BARAT
}

\author{
Estu Nugroho"\#, Sabara Putra"), Mohammad Ali Syahdan"), Lalu Mayadi"), \\ Sigit Budileksono"), dan Zulkifli" ${ }^{* * \prime}$ \\ ") Pusat Penelitian dan Pengembangan Perikanan Budidaya \\ ") Dinas Kelautan dan Perikanan Provinsi Nusa Tenggara Barat
}

(Naskah diterima: 2 April 2014; Revisi final: 6 Maret 2015; Disetujui publikasi: 11 Maret 2015)

\begin{abstract}
ABSTRAK
Evaluasi keragaan ikan lele hibrida dari hasil persilangan antara Masamo (M), Sangkuriang (S), dan Paiton (P) telah dilakukan untuk mendapatkan benih unggul ikan lele untuk budidaya di daerah Provinsi Nusa Tenggara Barat. Persilangan secara resiprokal telah dilakukan dengan menggunakan tiga strain ikan lele yaitu Masamo, Sangkuriang, dan Paiton masing-masing dengan empat ulangan. Pemijahan dilakukan secara alami dengan bantuan suntikan ovaprim. Nilai heterosis tertinggi pada tingkat pembenihan dan pembesaran ada pada pasangan hibrida S-M. Heterosis hibrida S-M di tingkat pembenihan adalah 6,68\% (sintasan) dan 2,79\% (pertambahan panjang benih), sedangkan di tingkat pembesaran 6,90\% (sintasan), 24,03\% (pertumbuhan bobot harian) dan -3,79\% (konversi pakan). Perkawinan betina Sangkuriang - jantan Masamo mempunyai nilai "heterosis" tertinggi pada semua parameter di tingkat pembenihan dan pembesaran.
\end{abstract}

KATA KUNCI: hibrida lele, Nusa Tenggara Barat, heterosis

ABSTRACT: $\quad$ Heterosis of hybrids catfish in West Nusa Tenggara Province. By: Estu Nugroho, Sabara Putra, Mohammad Ali Syahdan, Lalu Mayadi, Sigit Budileksono, and Zulkifli

Evaluation on performance of African hybrid catfish has been conducted to obtain a superior seeds for aquaculture in West Nusa Tenggara Province. Reciprocal matting was done using three strains of African catfish i.e. Masamo (M), Sangkuriang (S), and Paiton (P) with four replications. Natural spawning was used with injection of ovaprim hormone. The highest value of heterosis in nursery and grow up levels is observed in hybrids of S-M. The hybrid vigor of S-M in nursery level is $6.68 \%$ (survival) and 2.79\% (length), while those in grow up level is 6.90\% (survival), 24.03\% (weight), and $-3.79 \%$ (feed conversion ratio). Catfish hybrid produced from Sangkuriang-female and Masamo-male brood resulted the highest value in hybrid vigor for all of parameters in nursery and grow up levels.

KEYWORDS: catfish hybrid, West Nusa Tenggara Province, heterosis

\section{PENDAHULUAN}

Ikan lele dumbo pertama kali masuk ke Indonesia pada tahun 1986 yang dilakukan oleh suatu perusahaan swasta di Jakarta. Ikan ini merupakan hasil persilangan antara C. gariepinus (jantan) dan C. fuscus (betina) (Agriflo, 2013). Ikan lele merupakan salah satu komoditas perikanan air tawar yang dapat diunggulkan karena permintaan pasarnya yang selalu tinggi. Tercatat lebih dari 40 ton/bulan ikan lele konsumsi dibutuhkan untuk daerah Jakarta, Bogor, Depok, Tangerang, dan Bekasi (Jabodetabek) (Nugroho, 2007). Sayangnya animo yang demikian tinggi untuk ber-

\# Korespondensi: Pusat Penelitian dan Pengembangan Perikanan Budidaya. Jl. Ragunan No. 20, Pasar Minggu, Jakarta Selatan 12540, Indonesia. Tel.: + (021) 7805051 E-mail: engroho@yahoo.com usaha, seringkali tidak dibarengi suatu strategi yang tepat sehingga harapan untuk memperoleh keuntungan dari usaha budidaya lele tidak terwujud.

Perkembangan usaha budidaya ikan lele sangat pesat sehingga memberikan kontribusi yang sangat nyata terhadap peningkatan produksi perikanan budidaya. KKP (2011) mencatat bahwa produksi lele pada tahun 2011 sudah mendekati angka 350 ribu ton dengan percepatan pertumbuhan produksi per tahunnya mencapai $40 \%$. Keadaan ini semakin memperjelas kedudukan komoditas lele untuk budidaya ikan di Indonesia.

Keadaan yang sama juga terjadi di daerah Nusa Tenggara Barat. Dengan potensi luas perkolaman sekitar 8.960 ha dan perairan umum dengan 33.750 ha maka ikan lele lambat laun menjadi komoditas 
andalan di daerah tersebut (DKP Provinsi NTB, 2013). Tanpa mengesampingkan perkembangan yang pesat ini, terdapat permasalahan yang dapat menyebabkan kegagalan dalam budidaya ikan lele di masa mendatang. Salah satu di antaranya adalah semakin rendahnya kualitas benih ikan lele yang beredar di masyarakat, ditandai dengan semakin tingginya angka FCR (Feed Coversion Ratio) mencapai dua dan sintasan yang hanya mendekati angka 85\% (Personal Komunikasi).

Penyebab dari keadaan ini adalah adanya penggunaan induk-induk yang sudah tidak memenuhi syarat, baik dari segi kualitas maupun kuantitasnya pada saat pemijahan sehingga kemungkinan terjadinya kawin dalam atau inbreeding menjadi besar. Belum adanya induk-induk unggul ikan lele yang dihasilkan di Nusa Tenggara Barat, sehingga pembudidaya mendatangkan benih ikan lele dari Pulau Jawa menjadi salah satu alasan penggunaan benih dari induk-induk yang tidak memenuhi syarat tersebut.

Salah satu upaya untuk menanggulangi permasalahan tersebut adalah dengan melakukan program pemuliaan ikan lele yang sudah dimulai sejak tahun 2011. Beredarnya beberapa strain ikan lele di daerah Provinsi Nusa Tenggara Barat merupakan salah satu keuntungan di mana para pembudidaya sudah menguasai teknologi budidaya ikan lele dari berbagai strain tersebut. Program pemuliaan yang dijalankan selain seleksi adalah hibridisasi.

Hibridisasi merupakan salah satu upaya untuk mendapatkan benih unggul dengan memanfaatkan sifat heterosis karena sifat dominan dan heterozigot pada banyak lokus atau interaksi dari alel pada lokus (Tave, 1993). Falconer (1996) menyatakan bahwa hibridisasi dapat meningkatkan proporsi gen yang heterozigot namun menurunkan proporsi gen yang homozigot. Beberapa penelitian menunjukkan bahwa hibridisasi pada ikan dapat menghasilkan benih-benih dengan keunggulan tertentu misalnya lebih cepat tumbuh dan seragam pada perkawinan antara chanel catfish betina dengan catfish biru jantan (Brooks et al., 1982); hibrida huna (Kusmini, 2009), red tilapia cepat tumbuh (DKP Provinsi Jawa Tengah, 2012) dan pada persilangan lele dumbo Sangkuriang 2 (BBBAT Sukabumi, 2013).

Penelitian ini bertujuan untuk mengestimasi efek heterosis dari persilangan antara tiga strain ikan lele yaitu lele Masamo, Sangkuriang, dan Paiton.

\section{BAHAN DAN METODE}

\section{Jenis Ikan}

Ikan lele yang digunakan dalam kegiatan ini adalah induk ikan lele Masamo, Sangkuriang, dan Paiton. Sebelum dilakukan penyilangan antara tiga strain ikan lele tersebut, induk-induk terpilih dari masing-masing strain dikarakterisasi secara morfometrik.

Ikan lele Masamo yang digunakan merupakan ikan lele hasil pengembangan PT Matahari Sakti, Sidoarjo (2009) yang disebutkan salah satu induknya berasal dari Afrika, mempunyai keunggulan di antaranya adalah cepat tumbuh dan relatif toleran terhadap fluktuasi lingkungan.

Ikan lele Sangkuriang yang digunakan berasal dari Balai Besar Budidaya Air Tawar Sukabumi (BBBAT) yang didatangkan sejak tahun 2009. Lele ini merupakan hasil persilangan balik antara induk jantan lele dumbo dari F-2 dengan induk betina dari F-6. Ikan lele ini mempunyai pertumbuhan yang cepat dan daya tahan yang cukup baik terhadap serangan $A$. hydrophila.

Ikan lele Paiton yang digunakan berasal dari Balai Pengembangan Budidaya Ikan Air Tawar (BPBIAT) Yogyakarta didatangkan tahun 2009. Ikan lele ini sebenarnya hasil perkawinan antara induk betina asal Thailand dan induk jantan dumbo yang dilakukan pertama kali di daerah Paiton, Probolinggo, Jawa Timur. Lele ini mempunyai keunggulan cepat tumbuh, tahan terhadap penyakit, dan nafsu makan yang besar (Agriflo, 2013).

\section{Karakter Morfometrik Induk}

Secara morfometrik tidak terdapat perbedaan di antara ketiga strain yang digunakan dalam membuat hibrida yaitu Masamo, Sangkuriang, dan Paiton. Perbedaan hanya tercermin pada parameter diameter mata, lebar mulut, jarak antara dua mata, serta jarak antara ujung tutup insang bagian bawah ke ujung moncong (Tabel 1). Fenomena ini menandakan bahwa ketiga strain ini kemungkinan induknya secara umum adalah jenis yang sama yaitu lele dumbo. Hal ini diperkuat oleh Anonim (2014) yang mengamati pada ikan lele Paiton, Sangkuriang, dumbo lokal, dan lele Mesir.

\section{Persilangan}

Induk-induk yang sudah dikarakterisasi dipasangkan secara resiprokal dengan sembilan perlakuan, yaitu enam merupakan persilangan untuk mendapatkan hibrida sedangkan tiga persilangan untuk mendapatkan galur murni, masing-masing dilakukan empat ulangan (Tabel 2).

\section{Pemijahan dan Pemeliharaan Larva}

Pemijahan dilakukan dengan bantuan suntikan hormon ovaprim dan dipijahkan secara alami dalam kolam terpal yang dilengkapi dengan menggunakan kakaban sebagai alat penempel telur. Setelah lima hari, telur menetas dan kuning telur habis larva dikum- 
Tabel 1. Data morfometrik ketiga strain ikan lele yang digunakan sebagai induk Table 1. Morphometric of three strains of African catfish

\begin{tabular}{|c|c|c|c|}
\hline \multirow{2}{*}{$\begin{array}{l}\text { Deskripsi } \\
\text { Description }\end{array}$} & \multicolumn{3}{|c|}{ Strain } \\
\hline & Masamo & Sangkuriang & Paiton \\
\hline Panjang standar (PS) (Standar length) (SL) (cm) & $23.0-36.0$ & $24.0-37.0$ & $24.0-38.0$ \\
\hline Panjang kepala (PK) (Head length) (HL) (cm) & $6.2-9.7$ & $5.6-8.8$ & $5.9-9.3$ \\
\hline Tinggi badan (TB) (Body height) $(B H)(\mathrm{cm})$ & $3.8-6.0$ & $4.3-6.7$ & $4.2-6.6$ \\
\hline Lebar badan (LB) (Body width ) (BW) (cm) & $4.3-6.7$ & 4.5-7.0 & $4.5-6.9$ \\
\hline Rasio PS/PK (Ratio SL/HL) & $3.3-4.2$ & $3.7-4.6$ & $3.4-4.5$ \\
\hline Rasio PS/TB (Ratio SL/BH) & $5.1-7.2$ & $4.8-6.2$ & $5.3-6.3$ \\
\hline Rasio PS/LB (Ratio SL/BW) & $4.5-6.9$ & $4.5-7.0$ & 4.4-7.0 \\
\hline PK dalam \% PS (HL in \% SL) & $23.6-30.4$ & $21.6-27.1$ & $22.4-29.2$ \\
\hline TB dalam \% PS (BH in \% SL) & 13.9-19.6 & $16.2-20.8$ & $15.8-20.8$ \\
\hline LB dalam \% PS (BW in \% SL) & $15.3-21.7$ & $16.2-22.9$ & $15.8-22.9$ \\
\hline $\begin{array}{l}\text { Jarak sirip punggung ke ujung moncong (JSPM) (\% PS) } \\
\text { Distance between dorsal fin to mouth (in \% SL) }\end{array}$ & 31.9-43.5 & $29.7-41.7$ & $31.6-41.7$ \\
\hline $\begin{array}{l}\text { Diameter mata }(\mathrm{DM})(\% \mathrm{PK}) \\
\text { Eye diameter (in \% } H L)\end{array}$ & $5.7-5.8$ & $6.1-6.3$ & $5.7-5.9$ \\
\hline $\begin{array}{l}\text { Lebar mulut (LM) (\% PK) } \\
\text { Mouth width (in \% HL) }\end{array}$ & $42.9-47.1$ & $50.0-53.8$ & $57.1-58.8$ \\
\hline $\begin{array}{l}\text { Jarak antara dua bola mata (JBM) }(\% \mathrm{PK}) \\
\text { Distance between two eyes (in \% } \mathrm{HL})\end{array}$ & $57.1-58.8$ & $61.5-62.5$ & $70.6-71.4$ \\
\hline $\begin{array}{l}\text { Jarak antara ujung tutup insang bagian bawah ke } \\
\text { ujung moncong (\%PK) } \\
\text { Distance between bottom operculum to mouth (in \% HL) }\end{array}$ & $70.6-71.4$ & $75.0-76.9$ & $82.4-85.7$ \\
\hline $\begin{array}{l}\text { Jarak antara sirip dada ke ujung moncong (\% PS) } \\
\text { Distance between pectoral fin to mouth (in \% SL) }\end{array}$ & $19.4-26.1$ & $18.9-22.9$ & $21.1-29.2$ \\
\hline $\begin{array}{l}\text { Jarak antara sirip perut ke ujung moncong (\% PS) } \\
\text { Distance between ventral fin to mouth (in \% SL) }\end{array}$ & $47.2-60.9$ & $45.9-58.3$ & $44.7-58.3$ \\
\hline $\begin{array}{l}\text { Jarak antara sirip dubur ke ujung moncong (\% PS) } \\
\text { Distance between anal fin to mouth (in \% SL) }\end{array}$ & $50.0-65.2$ & $48.6-66.6$ & 47.4-66.6 \\
\hline Warna punggung (Dorsal colour) & $\begin{array}{l}\text { Hitam keabuan } \\
\text { Grayness black }\end{array}$ & $\begin{array}{l}\text { Hitam } \\
\text { Black }\end{array}$ & $\begin{array}{l}\text { Hitam kehijauan } \\
\text { Greeness black }\end{array}$ \\
\hline Warna perut (Ventral colour) & $\begin{array}{l}\text { Putih kekuningan } \\
\text { White-yellow }\end{array}$ & $\begin{array}{l}\text { Putih kekuningan } \\
\text { White-yellow }\end{array}$ & $\begin{array}{l}\text { Putih keabuan } \\
\text { White-grey }\end{array}$ \\
\hline
\end{tabular}

pulkan. Larva yang dihasilkan kemudian dipelihara di dalam wadah berupa akuarium dengan kepadatan 1.000 butir untuk setiap akuarium dengan ukuran $60 \mathrm{~cm} x$ $40 \mathrm{~cm}$ x $40 \mathrm{~cm}$ (ketinggian air $30 \mathrm{~cm}$ ). Larva dipelihara selama 14 hari dan diberi pakan Artemia pada minggu pertama secara adlibitum, sedangkan pada minggu kedua larva diberi pakan cacing Tubifex.

Selanjutnya dilakukan sortasi terhadap benih-benih ikan dengan menggunakan saringan terbuat dari bak plastik dengan lubang-lubang berdiameter $1-2 \mathrm{~cm}$. Benih yang tersortir dipelihara kembali selama 14 hari pada akuarium dengan kepadatan 1.000 ekor per wadah. Benih diberi pakan berupa cacing Tubifex. Tahapan berikutnya dilakukan sortasi dan penjarangan. Be- nih yang dihasilkan dipelihara kembali pada wadah akuarium dengan kepadatan 700 ekor/wadah yang dipelihara sampai umur 40 hari. Pakan yang digunakan adalah Tubifex. Sortasi dan penjarangan dilakukan kembali dan hasilnya dipelihara di akuarium sampai umur 80 hari dengan padat tebar 500 ekor. Pakan yang diberikan adalah cacing Tubifex secara adlibitum.

\section{Pembesaran}

Tahapan pembesaran dilakukan setelah ikan mencapai ukuran 10-12 g/ekor, yaitu sekitar umur 80 hari. Pembesaran dilakukan dengan menggunakan wadah berupa kolam terpal yang berukuran $2 \mathrm{~m}$ x $2 \mathrm{~m}$ x $1 \mathrm{~m}$ dengan ketinggian air sedalam $80 \mathrm{~cm}$. Kepadatan yang 
Tabel 2. Persilangan secara resiprokal

Table 2. Reciprocal matting for hybridization

\begin{tabular}{lccc}
\hline \multirow{2}{*}{$\begin{array}{c}\text { Betina } \\
\text { Female }\end{array}$} & \multicolumn{3}{c}{ Jantan (Male) } \\
\cline { 2 - 4 } & Masamo & Sangkuriang & Paiton \\
\hline \multirow{2}{*}{ Masamo } & 4 ulangan & 4 ulangan & 4 ulangan \\
& 4 repetition & 4 repetition & 4 repetition \\
Sangkuriang & 4 ulangan & 4 ulangan & 4 ulangan \\
& 4 repetition & 4 repetition & 4 repetition \\
Paiton & 4 ulangan & 4 ulangan & 4 ulangan \\
& 4 repetition & 4 repetition & 4 repetition \\
\hline
\end{tabular}

digunakan adalah 350 ekor/wadah $\left(90 \mathrm{ekor} / \mathrm{m}^{2}\right)$. Ikan diberi pakan berupa pelet terapung dengan kadar protein $32 \%$, dengan dosis pemberian $10 \%$ bobot biomassa dengan frekuensi pemberian $4 \mathrm{x}$ per hari (pukul 06.00; 12.00; 18.00; dan 20.00). Tahapan pembesaran ini dilakukan selama 55 hari, sampai ikan mencapai ukuran konsumsi.

\section{Analisis Data}

Parameter yang diamati dalam kegiatan ini adalah sintasan dan pertumbuhan saat pendederan, sintasan, dan pertumbuhan harian, serta konversi pakan saat pembesaran. Jumlah sampel dalam setiap sampling adalah 100 ekor untuk setiap perlakuan dan ulangan. Waktu sampling adalah hari ke-14, 50, dan 80 (pembenihan), hari ke-90, 105, dan 135 (pembesaran).

Data yang diperoleh dianalisis heterosisnya dengan menggunakan rumus Tave (1993):

$$
\text { Heterosis }=\frac{\text { RPS }- \text { RIP }}{\text { RIP }} \times 100 \%
$$

di mana:

RPS $=$ Rata-rata persilangan resiprokal

RIP $=$ Rata-rata induk pembentuk

Untuk mengukur keberhasilan pasangan tertentu dibandingkan induk pembentuknya maka digunakan rumus "heterosis parsial" dengan rumus sebagai berikut:

$$
\text { Heterosis persilangan } A B=\frac{H P-R I P}{R I P} \times 100 \%
$$

di mana:

$\mathrm{HP}=$ Hasil persilangan $\mathrm{AB}$

RIP = Rata-rata induk pembentuk

Sedangkan untuk menghitung nilai "maternal effect" maka digunakan rumus sebagai berikut:

"Maternal effect strain-i" = (Rata-rata hasil persilangan dengan betina-i) - Rata-rata induk pembentuk
Dan, nilai "individual effect" dihitung melalui persamaan sebagai berikut:

"Individual effect strain-i" = $($ Rata-rata persilangan resiprokal) - (Rata-rata induk pembentuk) - ("Maternal effect strain-i)

\section{HASIL DAN BAHASAN}

\section{Heterosis pada Level Pembenihan}

Secara umum, nilai sintasan yang diperoleh pada tingkat pembenihan sampai umur 80 hari adalah berkisar antara 76\% (betina Paiton-jantan Paiton) hingga 82,8\% (betina Sangkuriang-jantan Masamo). Heterosis pada tingkat pembenihan yaitu pada parameter sintasan menunjukkan bahwa hibridisasi mampu menaikkan sintasan sebesar 1,71\% dibandingkan galur murninya. Kenaikan terbesar didapatkan pada pasangan antara strain Masamo dengan Sangkuriang dengan nilai perbaikan sintasan sebesar 6,68\% dibandingkan galur murninya (Tabel 3). Sedangkan dua hibrida lainnya mempunyai sintasan yang lebih kecil dibandingkan galur murninya.

Kenaikan sintasan pada hibrida MS ini menunjukkan bahwa adanya pengaruh aditif dari perjumpaan antara alel dari Masamo dan Sangkuriang. Hal yang sama juga terjadi pada ikan gurame, hidrida gurame mempunyai sintasan yang lebih besar dibandingkan galur murninya (Nugroho et al., 2013); serta hibrida huna biru dan huna capit merah (Kusmini, 2009).

Selanjutnya, pengaruh induk betina terbesar diberikan oleh strain Sangkuriang $(0,75)$, sedangkan strain Masamo hanya memberikan pengaruh 0,2 . Hal ini berarti pasangan betina Sangkuriang dan jantan Masamo lebih baik dibandingkan sebaliknya. Sedangkan secara individu, strain Paiton mempunyai pengaruh yang terbesar.

Panjang rata-rata yang dicapai benih ikan lele sampai umur 80 hari berkisar antara $11,6 \mathrm{~cm}$ (betina Paiton-jantan Paiton) hingga 12,3 cm (betina Sangkuriang-jantan Masamo). Heterosis tentang pertumbuhan harian rata-rata ( $\mathrm{cm} / \mathrm{hari}$ ) pada tingkat pembenihan menunjukkan bahwa terjadi kenaikan sebesar 1,39\% secara total. Heterosis terbesar terdapat pada hibrida antara Masamo dan Sangkuriang (2,79\%) diikuti oleh hibrida Sangkuriang-Paiton $(1,25 \%)$ dan hibrida Masamo dan Paiton $(-0,46 \%)$ (Tabel 4).

Seperti pada hasil sintasan, hybrid vigor terjadi pada pasangan Masamo dan Sangkuriang dimungkinkan oleh faktor aditif dari alel yang bertemu (Falconer, 1985). Hal yang sama juga terjadi pada ikan gurame, hidrida gurame mempunyai pertumbuhan yang lebih baik dibandingkan galur murninya (Ariyanto \& Listyowati, 2011; Nugroho et al., 2013), serta ikan pa- 
Tabel 3. Heterosis pada sintasan ikan lele pada tingkat pembenihan

Table 3. Heterosis of survival rate at nursery level

\begin{tabular}{|c|c|c|c|c|}
\hline \multirow{2}{*}{$\begin{array}{c}\text { Sintasan } \\
\text { Survival rate (\%) }\end{array}$} & & \multicolumn{3}{|c|}{ Betina (Female) } \\
\hline & & Masamo (M) & Paiton (P) & Sangkuriang (S) \\
\hline \multirow{4}{*}{ Jantan (Male) } & Masamo (M) & 78.00 & 76.80 & 82.80 \\
\hline & Paiton (P) & 78.50 & 76.00 & 77.60 \\
\hline & Sangkuriang (S) & 81.50 & 77.40 & 79.30 \\
\hline & \multicolumn{3}{|c|}{ Deskripsi (Description) } & Nilai (Value) \\
\hline \multirow{4}{*}{\multicolumn{4}{|c|}{$\begin{array}{l}\text { Heterosis } \\
\text { - Heterosis kombinasi MS dan SM (Heterosis of MS and SM combination ) } \\
\text { - Heterosis kombinasi MP dan PM (Heterosis of MP and PM combination ) } \\
\text { - Heterosis kombinasi SP dan PS (Heterosis of SP and PS combination ) }\end{array}$}} & $1.71 \%$ \\
\hline & & & & $6.68 \%$ \\
\hline & & & & $-1.27 \%$ \\
\hline & & & & -0.13 \\
\hline \multicolumn{4}{|c|}{ Maternal effect-M } & 0.20 \\
\hline \multicolumn{4}{|c|}{ Maternal effect-S } & 0.75 \\
\hline \multicolumn{4}{|c|}{ Maternal effect-P } & -0.95 \\
\hline \multicolumn{4}{|c|}{ Individual effect $-\mathrm{M}$} & -0.52 \\
\hline \multicolumn{4}{|c|}{ Individual effect-S } & -0.82 \\
\hline \multicolumn{4}{|c|}{ Individual effect $-\mathrm{P}$} & 1.53 \\
\hline
\end{tabular}

Tabel 4. Heterosis pada pertumbuhan panjang harian ikan lele pada tingkat pembenihan Table 4. Heterosis for growth in length of African catfish at nursery level

\begin{tabular}{|c|c|c|c|c|}
\hline \multirow{2}{*}{$\begin{array}{l}\text { Panjang total } \\
\text { Total length }(\mathrm{cm})\end{array}$} & & \multicolumn{3}{|c|}{ Betina (Female) } \\
\hline & & Masamo (M) & Paiton (P) & Sangkuriang (S) \\
\hline \multirow{4}{*}{ Jantan (Male) } & Masamo (M) & $12.0 \pm 1.27$ & $11.8 \pm 1.16$ & $12.3 \pm 1.09$ \\
\hline & Paiton (P) & $12.0 \pm 1.10$ & $11.6 \pm 1.11$ & $11.9 \pm 1.20$ \\
\hline & Sangkuriang (S) & $12.2 \pm 1.09$ & $12.1 \pm 1.10$ & $11.9 \pm 1.28$ \\
\hline & \multicolumn{3}{|c|}{ Deskripsi (Description) } & Nilai (Value) \\
\hline \multicolumn{4}{|l|}{ Heterosis } & $1.39 \%$ \\
\hline \multicolumn{4}{|c|}{ - Heterosis kombinasi MS dan SM (Heterosis of MS and SM combination ) } & $2.79 \%$ \\
\hline \multicolumn{4}{|c|}{ - Heterosis kombinasi MP dan PM (Heterosis of MP and PM combination ) } & $-0.46 \%$ \\
\hline \multicolumn{4}{|c|}{ - Heterosis kombinasi SP dan PS (Heterosis of SP and PS combination ) } & $1.25 \%$ \\
\hline \multicolumn{4}{|c|}{ Maternal effect $-\mathrm{M}$} & 0 \\
\hline \multicolumn{4}{|c|}{ Maternal effect-S } & 0 \\
\hline \multicolumn{4}{|c|}{ Maternal effect-P } & 0 \\
\hline \multicolumn{4}{|c|}{ Individual effect-M } & 0.0015 \\
\hline \multicolumn{4}{|c|}{ Individual effect-S } & -0.0003 \\
\hline \multicolumn{4}{|c|}{ Individual effect $-\mathrm{P}$} & 0.0015 \\
\hline
\end{tabular}

tin P. djambal dan P. hypophtahlmus (Ariyanto \& Utami, 2005).

Meskipun secara maternal effect semua betina mempunyai pengaruh yang sama, namun berdasarkan pengaruh individu maka strain Masamo dan Paiton mempunyai nilai yang lebih tinggi dibandingkan Sangkuriang. Berdasarkan hasil analisis DNA (Nugroho et al., 2014), maka yang berpeluang sebagai kandidat adalah strain Masamo dibandingkan strain Paiton.

\section{Heterosis pada Level Pembesaran}

Nilai sintasan ikan lele pada pembesaran selama 55 hari berkisar antara 90,10\% (betina Paiton-jantan Paiton) hingga 97,60\% (betina Sangkuriang-jantan Masamo). Heterosis dari sintasan pada pembesaran ikan lele tercatat bahwa terjadi kenaikan akibat hybrid vigor sebesar $1,16 \%$ secara total pada sintasan ikan lele pada tingkat pembesaran. Heterosis terbesar disumbangkan oleh hibrida dari pasangan Masamo- 
Sangkuriang $(5,47 \%)$; sedangkan dua hibrida lainnya yaitu Masamo-Paiton dan Paiton-Sangkuriang terjadi penurunan sintasan dibandingkan masing-masing galur murninya yaitu sebesar $-1,61 \%$ dan $-0,21 \%$ (Tabel 5).

Nilai maternal effect terbesar dimiliki oleh strain Sangkuriang $(1,75)$. Jika dihitung estimasi nilai heterosis secara parsial, ternyata pasangan betina Sangkuriang-jantan Masamo mempunyai nilai hete- rosis lebih besar $(6,90 \%)$ dibandingkan nilai heterosis pasangan betina Masamo-jantan Sangkuriang. Nilai sintasan hibrida ini lebih besar dibandingkan dengan heterosis yang dimiliki oleh hibrida Sangkuriang-2 (BBBAT Sukabumi, 2013).

Bobot rata-rata yang dicapai oleh ikan lele pada saat pembesaran mempunyai range antara $122,4 \mathrm{~g}$ (betina Paiton-jantan Paiton) sampai 156,2 g (betina

Tabel 5. Heterosis sintasan ikan lele pada tingkat pembesaran

Table 5. Heterosis for survival rate at grow up level

\begin{tabular}{|c|c|c|c|c|}
\hline \multirow{2}{*}{$\begin{array}{c}\text { Sintasan } \\
\text { Survival rate (\%) }\end{array}$} & & \multicolumn{3}{|c|}{ Betina (Female) } \\
\hline & & Masamo (M) & Paiton (P) & Sangkuriang (S) \\
\hline \multirow{4}{*}{ Jantan (Male) } & Masamo (M) & 92.50 & 90.20 & 97.60 \\
\hline & Paiton (P) & 92.90 & 90.10 & 92.00 \\
\hline & Sangkuriang (S) & 95.00 & 91.10 & 93.60 \\
\hline & \multicolumn{3}{|c|}{ Deskripsi (Description) } & Nilai (Value) \\
\hline \multirow{4}{*}{\multicolumn{4}{|c|}{$\begin{array}{l}\text { Heterosis } \\
\text { - Heterosis kombinasi MS dan SM (Heterosis of MS and SM combination) } \\
\text { - Heterosis kombinasi MP dan PM (Heterosis of MP and PM combination ) } \\
\text { - Heterosis kombinasi SP dan PS (Heterosis of SP and PS combination ) }\end{array}$}} & $1.16 \%$ \\
\hline & & & & $5.47 \%$ \\
\hline & & & & $-1.61 \%$ \\
\hline & & & & $-0.12 \%$ \\
\hline \multicolumn{4}{|c|}{ Maternal effect $-\mathrm{M}$} & 0.05 \\
\hline \multicolumn{4}{|c|}{ Maternal effect-S } & 1.75 \\
\hline \multicolumn{4}{|c|}{ Maternal effect-P } & -1.8 \\
\hline \multicolumn{4}{|c|}{ Individual effect $-\mathrm{M}$} & -1.32 \\
\hline \multicolumn{4}{|c|}{ Individual effect-S } & -0.17 \\
\hline \multicolumn{4}{|c|}{ Individual effect $-\mathrm{P}$} & 1.53 \\
\hline
\end{tabular}

Tabel 6. Heterosis pada pertumbuhan harian (g/hari) ikan lele pada tingkat pembesaran Table 6. Heterosis for growth in weight (g/day) of African catfish at grow up level

\begin{tabular}{|c|c|c|c|c|}
\hline \multirow{2}{*}{$\begin{array}{c}\text { Bobot } \\
\text { Weight (g) }\end{array}$} & & \multicolumn{3}{|c|}{ Betina (Female) } \\
\hline & & Masamo (M) & Paiton (P) & Sangkuriang (S) \\
\hline \multirow{4}{*}{ Jantan (Male) } & Masamo (M) & $132.19 \pm 2.30$ & $143.35 \pm 3.41$ & $156.17 \pm 2.01$ \\
\hline & Paiton (P) & $137.03 \pm 2.75$ & $122.44 \pm 3.00$ & $132.75 \pm 2.34$ \\
\hline & Sangkuriang (S) & $152.86 \pm 2.22$ & $132.16 \pm 3.07$ & $123.46 \pm 3.26$ \\
\hline & \multicolumn{3}{|c|}{ Deskripsi (Description) } & Nilai (Value) \\
\hline \multicolumn{4}{|l|}{ Heterosis } & $13.80 \%$ \\
\hline \multicolumn{4}{|c|}{ - Heterosis kombinasi MS dan SM (Heterosis of MS and SM combination) } & $22.76 \%$ \\
\hline \multicolumn{4}{|c|}{ - Heterosis kombinasi MP dan PM (Heterosis of MP and PM combination) } & $10.68 \%$ \\
\hline \multicolumn{4}{|c|}{ - Heterosis kombinasi SP dan PS (Heterosis of SP and PS combination ) } & $5.17 \%$ \\
\hline \multicolumn{4}{|c|}{ Maternal effect -M } & -0.086 \\
\hline \multicolumn{4}{|c|}{ Maternal effect -S } & 0.03 \\
\hline \multicolumn{4}{|c|}{ Maternal effect-P } & -0.055 \\
\hline \multicolumn{4}{|c|}{ Individual effect-M } & 0.073 \\
\hline \multicolumn{4}{|c|}{ Individual effect-S } & -0.113 \\
\hline \multicolumn{4}{|c|}{ Individual effect $-\mathrm{P}$} & -0.045 \\
\hline
\end{tabular}


Tabel 7. Heterosis pada FCR ikan lele pada tingkat pembesaran Table 7. Heterosis for FCR of African catfish at grow up level

\begin{tabular}{|c|c|c|c|c|}
\hline \multirow{2}{*}{\multicolumn{2}{|c|}{$\begin{array}{l}\text { Rasio konversi pakan } \\
\text { Feed convertion ratio }\end{array}$}} & \multicolumn{3}{|c|}{ Betina (Female) } \\
\hline & & Masamo (M) & Paiton (P) & Sangkuriang (S) \\
\hline \multirow{4}{*}{ Jantan (Male) } & Masamo (M) & 1.18 & 1.18 & 1.14 \\
\hline & Paiton $(\mathrm{P})$ & 1.16 & 1.16 & 1.17 \\
\hline & Sangkuriang (S) & 1.14 & 1.14 & 1.2 \\
\hline & \multicolumn{2}{|c|}{ Deskripsi (Description) } & & Nilai (Value) \\
\hline \multicolumn{4}{|c|}{ Heterosis } & $-2.80 \%$ \\
\hline \multicolumn{4}{|c|}{ - Heterosis kombinasi MS dan SM (Heterosis of MS and SM combination ) } & $-3.79 \%$ \\
\hline \multicolumn{4}{|c|}{ - Heterosis kombinasi MP dan PM (Heterosis of MP and PM combination) } & $-2.52 \%$ \\
\hline \multicolumn{4}{|c|}{ - Heterosis kombinasi SP dan PS (Heterosis of SP and PS combination) } & $-1.39 \%$ \\
\hline \multicolumn{4}{|c|}{ Maternal effect $-\mathrm{M}$} & 0 \\
\hline \multicolumn{4}{|c|}{ Maternal effect -S } & 0 \\
\hline \multicolumn{4}{|c|}{ Maternal effect-P } & 0 \\
\hline \multicolumn{4}{|c|}{ Individual effect-M } & -0.01 \\
\hline \multicolumn{4}{|c|}{ Individual effect-S } & 0 \\
\hline \multicolumn{4}{|c|}{ Individual effect $-\mathrm{P}$} & 0.01 \\
\hline
\end{tabular}

Sangkuriang-jantan Masamo). Kenaikan nilai akibat hybrid vigor juga terjadi pada pertumbuhan rata-rata harian $(\mathrm{g} /$ hari). Nilai heterosis total tercatat sebesar $13,8 \%$; yang terdiri atas sumbangan nilai heterosis $\mathrm{MS}=22,76 \%$ MP $=10,68 \%$; dan SP $=5,17 \%$. Hibrida ikan lele dari strain betina Masamo-jantan Sangkuriang mempunyai nilai heterosis lebih besar dibandingkan nilai yang dihasilkan oleh ikan lele Sangkuriang-2 oleh tim BBBAT. Estimasi nilai heterosis pada pertumbuhan harian hibrida dari pasangan betina Sangkuriangjantan Masamo sedikit lebih besar dibandingkan nilai serupa yang dihasilkan pasangan sebaliknya. Hal ini juga ditunjukkan oleh kemampuan betina strain Sangkuriang dalam memberikan "effect maternal" (Tabel 6).

Rata-rata nilai FCR (Feed Conversion Ratio) berkisar antara 1,2 (betina Paiton-jantan Paiton) sampai 1,14 (betina Sangkuriang-jantan Masamo dan betina Masamo-jantan Sangkuriang). Nilai ini setara dengan yang didapatkan oleh lele Sangkuriang-2 (BBBAT, 2013).

Nilai heterosis pada parameter FCR ini menunjukkan terjadi perbaikan sebesar -2,8\% (penurunan heterosis total). Nilai penurunan heterosis terbesar terdapat pada hibrida MS $(-0,045)$ diikuti oleh hibrida MP $(-0,030)$ dan hibrida SP $(-0,025)$. Walaupun nilai efek betina $=0$, namun secara individu strain Masamo mempunyai nilai penurunan sebesar $-0,01$. Penurunan nilai FCR yang terjadi pada pasangan betina Sangkuriang-jantan Masamo sama besarnya dengan nilai penurunan pada hibrida betina Masamo-jantan Sangkuriang (Tabel 7).

\section{KESIMPULAN}

Pasangan MS (Masamo-Sangkuriang) mempunyai nilai heterosis terbaik pada sintasan saat pembenihan $(6,68 \%)$; pertumbuhan panjang benih $(2,79 \%)$; sintasan saat pembesaran $(6,90 \%)$; pertumbuhan harian saat pembesaran $(24,03 \%)$; dan FCR $(-3,79 \%)$.

\section{DAFTAR ACUAN}

Anonim. (2014). Naskah akademik rilis ikan lele tumbuh cepat hasil seleksi individu. Balai Penelitian Pemuliaan Ikan. Sukamandi, $234 \mathrm{hlm}$.

Agriflo. (2013). Lele peluang bisnis dan kisah sukses. Penebar Swadaya. Jakarta, $200 \mathrm{hlm}$.

Ariyanto, D., \& Listyowati, N. (2011). Performance and heterotic estimation of growth in intraspecific crossing of giant gouramy. Indonesian Aquaculture Journal, 6(1), 11-17.

Ariyanto, D., \& Utami, R. (2005). Evaluasi pertumbuhan, keragaman genetik dan estimasi heterosis pada persilangan antar spesies ikan patin (Pangasius sp.). Jurnal Perikanan, VII(1), 81-86.

Balai Besar Budidaya Air Tawar Sukabumi. (2013). Naskah pelepasan ikan lele Sangkuring-2. BBBATSukabumi.

Brooks, M.J., Smitherman, R.O., Chappell, J.A., \& Dunham, R.A. (1982). Sex-weight relation in blue channel, and white catfishes: implication for broodstock selection. Prog. Fish Cult., 44, 105-107.

Dinas Kelautan dan Perikanan Provinsi Jawa Tengah. (2012). Naskah permohonan pelepasan induk nila 
putih janti jantan dan induk nila hitam pandu betina sebagai induk unggul. Balai Pengembangan Budidaya Ikan Air Tawar, Muntilan. Yogyakarta, 74 hlm.

Dinas Kelautan dan Perikanan Provinsi Nusa Tenggara Barat. (2013). Naskah pelepasan ikan lele hibrida. Balai Pengembangan Teknologi Perbenihan dan Budidaya Ikan Air Tawar, 50 hlm.

Falconer, D.S. (1996). Introduction to quantitative genetics. Longman Malaysia, p. 281-288.

Kusmini, I.I. (2009). Karakteristik fenotipe dan genotipe hibrida antara huna biru (Cherax albertisii) dengan huna capit merah (Cherax quadricarinatus). Tesis Master. Sekolah Pasca Sarjana, Institut Pertanian Bogor. Bogor, $54 \mathrm{hlm}$.

Kementerian Kelautan dan Perikanan. (2011). Statistik perikanan Indonesia 2010.
Nugroho, E. (2007). Kiat agribisnis lele. Penebar Swadaya. Jakarta, $73 \mathrm{hlm}$.

Nugroho, E., Subagja, J., Sulhi, M., \& Kusdiarti. (2013). Efek heterosis pada hibrida ikan gurame (Osphronemus gouramy) dari varietas Soang, Paris, dan Blusafir. Forum Inovasi Teknologi Akuakultur 2013, Nusa Tenggara Barat.

Nugroho, E., Putera, S., Laksono, S., Rustandi, S., \& Aminollah. (2014). Hybrid candidates at Nusa Tenggara Barat Province based on the RAPD marker. Submitted to Indonesian Aquaculture Journal.

Tave, D. (1993). Genetics for fish hatchery managers. AVI Publishing Company, Inc. Westport. Connecticut, 299 pp. 